\title{
Toward economic growth: Income distribution in the era of the COVID19 pandemic in east Kalimantan province
}

\author{
Abdul Mukti Syarif ${ }^{a}$, Rahcmad Budi Suharto ${ }^{a^{*}}$, Zamruddin Hasid ${ }^{a}$, M. Saleh Mire ${ }^{a}$, Jiuhardi \\ and Made Setini ${ }^{b}$
}

${ }^{\mathrm{a}}$ Faculty of Economics and Business, Mulawarman University, Samarinda, Indonesia ${ }^{b}$ Faculty of Economics and Business, Udayana University, Bali, Indonesia

\section{H R O N I C L E}

\section{Article history:}

Received June 18, 2021

Received in revised format June

282021

Accepted July 22021

Available online

July 52021

Keywords:

Growth Economy

Income Distribution

Pandemic COVID19

\begin{abstract}
A B S T R A C T
The technological era is a dilemma in the economic growth of a region. The policy of economic development, at least, contains two main objectives to be achieved, namely growth and equity. These two goals are usually in conflict with each other. That is, if growth reaches a high level, then equity reaches a decline so that the conscious effort to create a balance is one of the goals of development. Growth to increase income per capita is an effort in progress to increase output (through the use of factors of production with or without technological change) continuously in the long run, which is always associated with population growth. Because with high output growth coupled with high population growth, the growth of output will become a new problem, so efforts to overcome unemployment are also a crucial part of development. Equitable distribution of fixed income is one of the critical issues faced by an economy. Doing a real business venture so that the rent is more evenly distributed is an essential responsibility of an economic system. The development of an economy will cause changes that are not always good due to the use of labor. This sometimes causes the number and level of unemployment to increase, along with population growth. Finally the paper considers whether there is any evidence of government expenditure, Private investment and poverty rates on Income distribution in East Kalimantan Province is Significantly influenced but Economic is not Growth.
\end{abstract}

\section{Introduction}

In the community economy, there are four basic reasons for the need for government intervention in expenditure through and government revenues, namely: (i) market failure; (ii) Unequal distribution of welfare and income (even distribution); (iii) Maintaining economic disruption (disruption); and (iv) promote economic growth (high growth). The reasons for growth and development, stability and growth are expressly stated as the goals of national development in the State Policy Guidelines (GBHN). Development Trilogy is strived to be implemented simultaneously in order to fulfill the goals of the welfare of the Indonesian people as all (Espinosa et al., 2021). However, in practice, the goals of equity and growth simultaneously cannot be easily achieved because of the scale of opportunity, the two goals are trade-offs because of the budgetary budget (Gadhok et al., 2020). Historically, it can also be seen that the performance of the Indonesian government in the past was able to increase its economic growth rapidly, even reaching a growth rate of $7 \%$ per year during the Old Order of President Soeharto (Gupta, 2020). This figure has earned Indonesia the nickname as the new "Asian Tiger" which is projected to be able to overtake other Asian countries such as South Korea, Japan and Singapore (Dayley, 2019). However, historically it has also been seen that the Indonesian government's efforts to achieve equity goals have not always

* Corresponding author

E-mail address: suhartorb80@gmail.com (R. B. Suharto) 
been successful (Erlina \& Muda, 2017). Data from the Central Statistics Agency (BPS) shows that in 1978 the level of inequality in per capita income in Indonesia was quite high, however in 1982 and 1984 it could be said that the level of inequality in per capita income was moderate (Kim et al., 2017). Even in 1987, inequality was low. The lessons that Indonesia experienced during the financial crisis that began at the end of 1997 do not seem to have made the Indonesian government in the reform era learn from its mistakes. It seems that high levels of economic growth without being based on stability and equity are more likely to occur (Maulidia et al., 2019). Political, legal, social and economic decision makers in the reform era seem to be still focused on efforts to restore the economy, which tends to be directed towards achieving high levels of economic growth again as achieved before the 1998 financial crisis.

Studies discussing the effect of government spending on economic growth have been carried out with ambiguous results, theoretically and empirically. Several empirical studies show a positive and significant relationship between growth and government spending (Hajamini \& Falahi, 2018; Hailemariam \& Dzhumashev, 2019), but other studies show the opposite relationship even not showing a significant relationship at all. On the other hand, there are quite a lot of studies studying the effect of government spending on the distribution or distribution of income and welfare (Cox et al., 2020; Mishchuk et al., 2020). However, the available empirical results show that the results of the study also vary because they really depend on what indicators are used as proxies of income distribution or distribution. The social aspect is very strong in assessing the level of the distribution of welfare / income in a country or region (Alemzero et al., 2020), therefore the use of indicators is widely used. Such as The Economic Freedom Index as a measure of whether a society is free to choose the economic sector as its livelihood is starting to be widely used. However, in this study the authors tend to get closer to the economic side of the paradigm of equal distribution of welfare through the distribution of income among community income groups.

This paper will try to evaluate and analyze the influence of East Kalimantan government spending, private investment, economic growth and poverty levels on income distribution using the annual data of the East Kalimantan provincial government from 2000 to 2019 . Government spending is a reflection of the government's ability to provide public services as well as the measure of the size of government. Private investment is summarized in domestic and foreign private sectors (PMDN and PMA). The rate of economic growth shows the percentage increase in the real Province's income in a certain year compared to the real Province's income in the previous year. Head Count Index (HCI-P0) or poverty rate reflects the percentage of population with income below the poverty line to the total population. The distribution of income according to the topic of this paper is an indicator of how the distribution of welfare can be encouraged or improved through government intervention via government expenditure and services. Of course, the assumption for this role of government spending is that government services that cannot be specifically allocated will be distributed based on family income or tax burden (Luintel et al., 2020). Furthermore, it is assumed that the influence of the taxation system, especially for the tax system based on the uses of income approach and social support from the private sector, is considered constant. This paper is divided into several discussions, namely: (i) a review of previous studies on the same topic; (ii) discussion of methods to be used to analyze the relationship between dependent and independent variables and; (iii) analysis and discussion of data processing results; and the last part is (iv) conclusions and suggestions.

\section{Literatur Review}

\subsection{Public Expenditure Private Investment, Economic Growth and Poverty}

Opinian Touchton (2019) uses a non-linear income tax model with data from The United Kingdom CSO and uses indicators of allocated government spending and distribution of community groups based on income as a proxy for the variables that explain the relationship between government spending and income distribution. (Sassi et al., 2019) shows that a greater distribution of government spending among high-income household groups will result in the top $20 \%$ of income earners enjoying $70 \%$ of expenditure compared to the lowest $20 \%$.

By using annual data from The United Kingdom Central Statistical Office (CSO) and the non-linear income tax model, we try to explain the effect of economic growth on income distribution which is proxied by the standard deviation of the amount of income tax obtained from its income base (Atkinson, 2017). Index. The conclusion is that differences in economic growth cannot be used as the cause of inequality in people's final income. A balanced distribution that tends to favor high-income groups can still reduce income inequality. It is also concluded that the distribution of more expenditure to low-income groups will significantly reduce income inequality, but if the portion is excessive, it will result in contra-productive distribution.

Hartono et al. (2021) analyzed the effect of investment spending on Indonesia's 2017 socio-economic balance system. They grouped income into 3 groups: wages and salaries, capital income, and transfer receipts. The grouping of investment expenditure is final consumption, transfer payments, and savings. They then calculated the disposable income per capita by household class and calculated the ratio of income and population classified in the agricultural and non-agricultural, rural and urban groups (Guth et al., 2020). Finally, they calculated Indonesia's Gini coefficient per year. The results obtained indicated that the non-agricultural household group, the urban upper class, was the recipient of the highest disposable income, namely 8.51 times the income of the farm laborer household group. Overall, rural residents only receive $29.85 \%$ 
of the national average per capita income while urban residents receive $70.15 \%$. The resulting Gini coefficient shows that the distribution of household income in Indonesia in 2017 is still relatively even with a moderate level of inequality.

Paprotny (2021) analyzed the relationship between poverty levels and several aspects of the socio-economic life of people in third world countries, from 1870 to mid 1990. Socio-economic aspects affected by poverty levels and analyzed in their study are: (i) state fiscal sustainability; (ii) the performance of the unemployment rate and economic growth; (iii) income distribution and human development. Specifically for the influence of the poverty level on income distribution, using descriptive and inferential statistics methods concluded that the poverty rate causes a movement towards equality in the distribution pattern of people's income (Bantis \& Hawort, 2020).

From the literature review that has been discussed, it can be seen that empirical evidence from the analysis of the relationship between government spending and income distribution shows ambiguous results. However, the conservative economic opinion that higher government spending will increase the amount of social transfers and increase the level of better public services so that a more equitable distribution of income and high economic growth can be achieved is supported by many economic thinkers. With the same frame of mind, many economic thinkers believe that Wagner's Law applies where an increase in government spending is a risk that must be faced by many countries if there is a faster rate of economic growth.

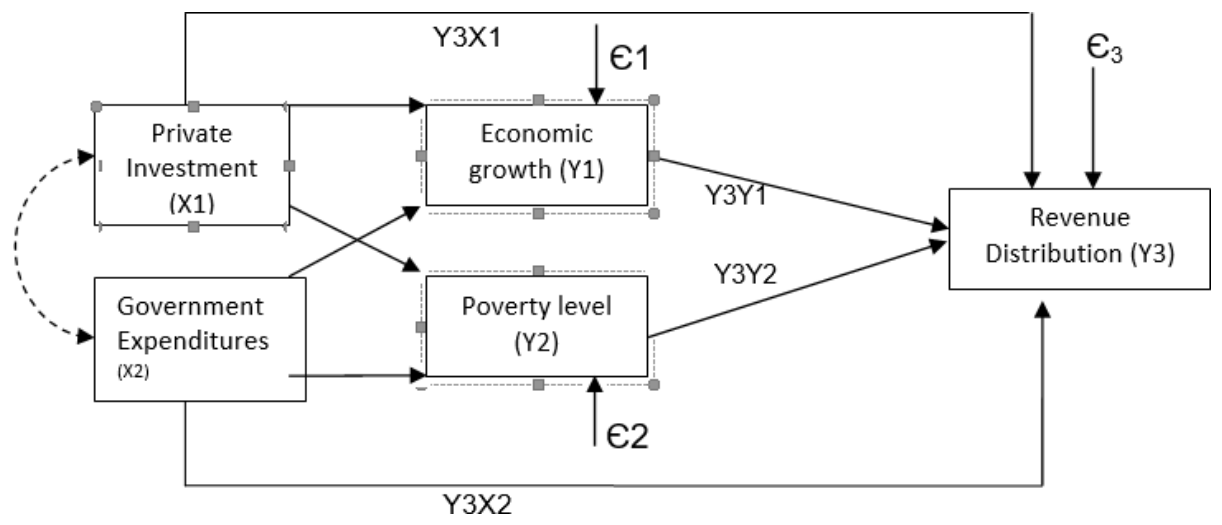

Fig 1. Frame Model AMOS

\section{Method}

The data analysis used in this research is Path Analysis using the AMOS program. However, several stages of analysis will be carried out to form a good model. The data input used in this study is the variance / covariance matrix. The program was chosen in this study because it was considered as a reliable program for the decomposition model of the influence of causality. Amos has advantages compared to other software. The data used in this study are the time series from 2000 2019. Meanwhile, the model developed to see the effect of government spending, private investment, poverty rate, economic growth on income distribution is explained next.

\section{Results}

The following Fig. 1 and Table 1 and Table 2, show the estimation results for the regressed model with the help of statistical software AMOS ver 20.0

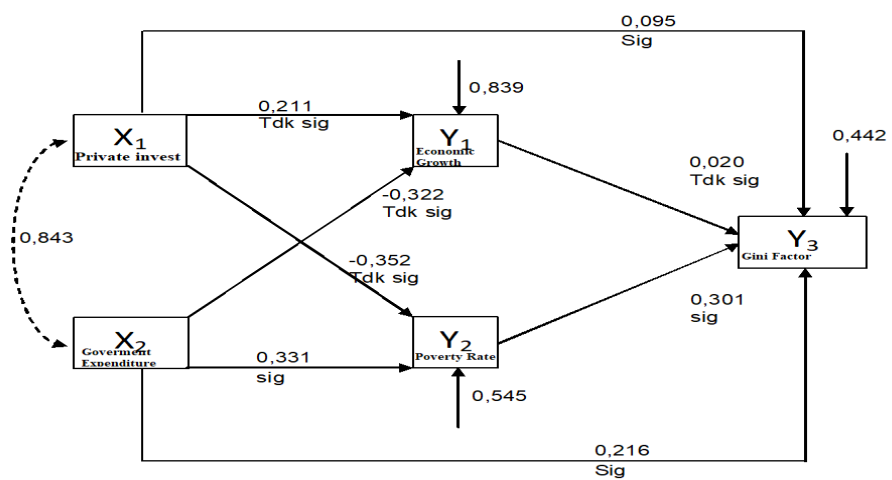

Fig 2. Results with AMOS 
Table 1

The results of direct and indirect effects

\begin{tabular}{|c|c|c|c|}
\hline \multirow[t]{2}{*}{ Influence of Variables } & \multicolumn{3}{|c|}{ Influence } \\
\hline & $\begin{array}{l}\text { Direct } \\
\text { (DE) }\end{array}$ & $\begin{array}{l}\text { Indirect } \\
\text { (IE) }\end{array}$ & Total $\mathrm{TE}=\mathrm{DE}+\mathrm{IE}$ \\
\hline $\mathrm{Y} 3 \rightarrow \mathrm{X} 1$ & 1.0404 & -1.3826 & -0.3422 \\
\hline $\mathrm{Y} 3 \rightarrow \mathrm{X} 2$ & 1.8118 & -0.9226 & 0.8892 \\
\hline $\mathrm{Y} 3 \rightarrow \mathrm{Y} 1$ & 0.0339 & -0.0348 & -0.0009 \\
\hline $\mathrm{Y} 3 \rightarrow \mathrm{Y} 2$ & 0.1261 & 0.1336 & 0.2597 \\
\hline Joint Influence & & & 0.805 \\
\hline
\end{tabular}

Source: Processed with AMOS

Table 2

The results of R-Square values

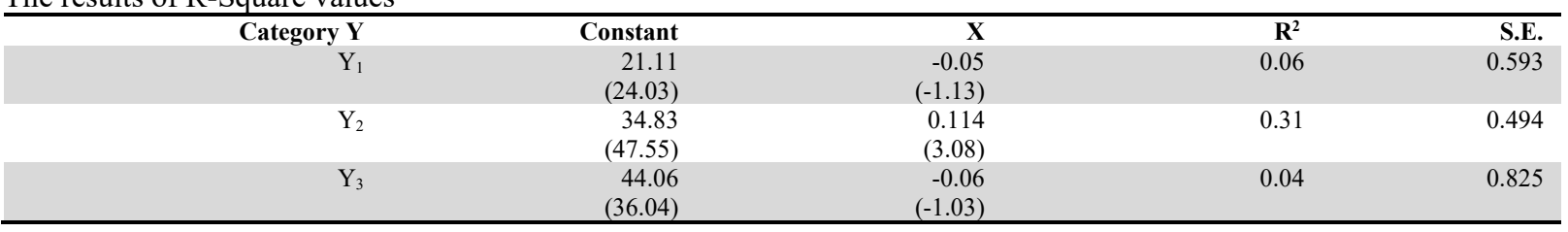

The estimation results show that the level of inequality in income distribution in the province of East Kalimantan is low according to the Gini standard. The role of government spending is proven to have the strongest role in distributing income in this province. This should be the concern of all stakeholders so that they continue to develop this factor if they want to continue to distribute income in East Kalimantan Province. The interpretation of the coefficient is that if government spending increases by 1 percent then the share of the Gini Factor will change by 0.216 percent. And this estimate is significant. Although the effect of changes in government spending is very strong on these two categories of community groups, from these results it can be temporarily concluded that there is a decrease in the share of GDP controlled by high-income groups due to the influence of increased government spending, and this increase in government spending helps the lives of these groups of poor people. On the other hand, the relationship between the ratios of private investment to the Gini factor is positive. This means that if there is a $1 \%$ increase in the ratio of private investment, the share of the Gini factor will increase by $0.095 \%$. The insignificance of the effect of economic growth in the province of East Kalimantan is probably due to the large number of employees receiving private companies from outside the province. We can expect an increase in the share of spending in the market in the province, but that is not the case for some of these employees. Because their family members are still outside the province, the salaries they receive will mostly be transferred to their families outside the province. Unlike the government employees who are paid from government spending, their families are in the province. So that their and their families spend, almost certainly a lot of it is done in markets within the province, so that there is a direction of equity. However, of course we hope that the increase in private investment will not be an obstacle to the distribution of income in East Kalimantan Province. Policy steps must be taken immediately so that this points to equity. Private investment in East Kalimantan has an insignificant effect on economic growth and poverty levels. Where a $1 \%$ increase in private investment will have the impact of increasing $0.211 \%$ economic growth and reducing $0.352 \%$ of the poverty rate. Income distribution in East Kalimantan decreases with increasing private investment, government spending, economic growth and poverty levels. $1 \%$ increase Private investment will decrease income distribution by $0.095 \%$. A $1 \%$ increase in Local government spending will decrease $0.216 \%$ of revenue distribution. An increase in economic growth of $1 \%$ will reduce $0.020 \%$ of income distribution. An increase in the poverty rate of $1 \%$ will decrease the income distribution by $0.301 \%$. There are other factors that affect the distribution of income beyond the four factors above. If this factor increases by $1 \%$, it will have an effect of $0.440 \%$ on the income distribution. To test whether the estimation results of the effect of the ratio of government expenditure on GDP with the distribution of income obtained by each equation in the model system are different from one another, the authors conducted a Wald test. Wald test is performed to test whether there is a statistical difference between the estimates in each equation in the model. The results obtained are as follows

Table 3

Result Chi-square and Wald test

System: SUR1

\begin{tabular}{llll}
$\begin{array}{l}\text { Null } \\
\text { Hypothesis: }\end{array}$ & $\alpha_{1}=\beta_{1}$ & & \\
\hline Chi-Square & 9.446402 & Probability & 0.002116 \\
\hline
\end{tabular}

System: SUR2

\begin{tabular}{llll}
$\begin{array}{l}\text { Null } \\
\text { Hypothesis: }\end{array}$ & $\alpha_{1}=\gamma_{1}$ & & \\
\hline Chi-Square & 0.017480 & Probability & 0.894817 \\
\hline
\end{tabular}

Source: Processed with AMOS

With the p-value, namely the final limit for the level of confidence that Ho can reject is 0.002116 , Ho is rejected, the conclusion is that there is a significant difference between the estimated effect of the ratio of government spending on GDP on the share of GDP owned by the poorest $40 \%$ of the population and $40 \%$ of the middle-income population. On the other hand, the p-value of 0.8948 indicates that there is no significant difference between the estimated effect of the ratio of government expenditure to GDP on the share of GDP owned by the poorest $40 \%$ of the population and $20 \%$ of the highincome population. The results of this test imply that the effect of changes in the ratio of government expenditure to GDP 
is indeed different for each of the income distributions of the poorest people in Indonesia, namely negative towards equal distribution and positively increasing the degree of inequality.

\section{Conclusion}

Referring to the discussion section, to answer the desired objectives in this study, the authors conclude that the effect of increasing government spending, private investment, economy growth and poverty rate in East Kalimantan is not significant in increasing the share of GDP that is owned by $40 \%$ of the middle-income population, but not for the poorest $40 \%$ of the population and $20 \%$ of the high income population. Therefore, it is not clear what variabel to the influence of the actual distribution occurs. Implicitly, this also implies that there may be a need for an effort to reform or reform the government spending system, starting from the concept, in relation to aspects of government revenue (for example taxes and BUMN profits), to the technical allocation and distribution to each community group. And also, there is a need for a reform of policy in staff that are hired in private companies that invest in east Kalimantan. Local people need to be educated until they can work in a private company. Not only immigrants from other islands that are hired in private companies. In this way, the money from salaries in private companies can stay in east kalimantan in the long term. The money can cycle in east kalimantan, to promote other businesses.

\section{References}

Atkinson, A. B. (2017). Pareto and the upper tail of the income distribution in the UK: 1799 to the present. Economica, 84(334), 129-156.

Alemzero, D. A., Sun, H., Mohsin, M., Iqbal, N., Nadeem, M., \& Vo, X. V. (2021). Assessing energy security in Africa based on multi-dimensional approach of principal composite analysis. Environmental Science and Pollution Research, 28(2), 2158-2171.

Bantis, T., \& Haworth, J. (2020). Assessing transport related social exclusion using a capabilities approach to accessibility framework: A dynamic Bayesian network approach. Journal of Transport Geography, 84, 102673.

Cox, N., Ganong, P., Noel, P., Vavra, J., Wong, A., Farrell, D., ... \& Deadman, E. (2020). Initial impacts of the pandemic on consumer behavior: Evidence from linked income, spending, and savings data. Brookings Papers on Economic Activity, 2020(2), 35-82.

Dayley, R. (2019). Southeast Asia in the new international era. Routledge.

Erlina, A. S., \& Muda, I. (2017). Antecedents of Budget Quality Empirical Evidence from Provincial Government In Indonesia. International Journal of Economic Research, 14(12), 301-312.

Espinosa, Á. V., López, J. L. L., Mata, F. M., \& Estevez, M. E. E. (2021). Application of IoT in Healthcare: Keys to Implementation of the Sustainable Development Goals. Sensors, 21(7), 2330.

Gadhok, I., Hepburn, G., Bellman, J., \& Krivonos, E. (2020). Trade and Sustainable Development Goal 2-Policy options and their trade-offs. Food \& Agriculture Org.

Gupta, K. (2020). The Importance of Financial Liberalisation to Economic Growth: The Case of Indonesia. Bulletin of Indonesian Economic

Guth, M., Smędzik-Ambroży, K., Czyżewski, B., \& Stępień, S. (2020). The economic sustainability of farms under common agricultural policy in the european union countries. Agriculture, 10(2), 34 .

Hailemariam, A., \& Dzhumashev, R. (2019). Fiscal equalization and composition of subnational government spending: implications for regional convergence. Regional Studies, 53(4), 587-601. Studies, (just-accepted), 1-32.

Hajamini, M., \& Falahi, M. A. (2018). Economic growth and government size in developed European countries: A panel threshold approach. Economic Analysis and Policy, 58, 1-13.

Hartono, D., Hastuti, S. H., Halimatussadiah, A., Saraswati, A., Mita, A. F., \& Indriani, V. (2020). Comparing the impacts of fossil and renewable energy investments in Indonesia: A simple general equilibrium analysis. Heliyon, 6(6), e04120.

Luintel, K. B., Matthews, K., Minford, L., Valentinyi, A., \& Wang, B. (2020). The role of Provincial Government Spending Composition in growth and convergence in China. Economic Modelling, 90, 117-134.

Maulidia, M., Dargusch, P., Ashworth, P., \& Ardiansyah, F. (2019). Rethinking renewable energy targets and electricity sector reform in Indonesia: A private sector perspective. Renewable and Sustainable Energy Reviews, 101, $231-247$.

Mishchuk, H., Bilan, S., Yurchyk, H., Akimova, L., \& Navickas, M. (2020). Impact of the shadow economy on social safety: The experience of Ukraine. Economics \& Sociology, 13(2), 289-303.

Paprotny, D. (2021). Convergence Between Developed and Developing Countries: A Centennial Perspective. Social indicators research, 153(1), 193-225.

Sassi, F., Belloni, A., Mirelman, A. J., Suhrcke, M., Thomas, A., Salti, N., ... \& Nugent, R. (2018). Equity impacts of price policies to promote healthy behaviours. The Lancet, 391(10134), 2059-2070.

Yang, M., Dong, S., Dong, Q., Xu, Y., Zhi, Y., Liu, W., \& Zhao, X. (2021). Trade-offs in ecological, productivity and livelihood dimensions inform sustainable grassland management: Case study from the Qinghai-Tibetan Plateau. Agriculture, Ecosystems \& Environment, 313, 107377. 
(c)

(C) 2022 by the authors; licensee Growing Science, Canada. This is an open access article distributed under the terms and conditions of the Creative Commons Attribution (CC-BY) license (http://creativecommons.org/licenses/by/4.0/). 